\title{
Post-caldera volcanism reveals shallow priming of an intra-ocean arc andesitic caldera: Hunga volcano, Tonga, SW Pacific
}

\author{
Marco Brenna ${ }^{1}$, Shane J. Cronin ${ }^{2}$, Ian E.M. Smith ${ }^{2}$, Alessio Pontesilli ${ }^{3}$, Manuela Tost ${ }^{4}$, Simon \\ Barker $^{5}$, Sisi Tonga'onevai ${ }^{6}$, Taaniela Kula ${ }^{6}$, and Rennie Vaiomounga ${ }^{6}$ \\ ${ }^{1}$ Department of Geology, University of Otago, Dunedin, New Zealand \\ ${ }^{2}$ School of Environment, University of Auckland, Auckland, New Zealand \\ ${ }^{3}$ Istituto Nazionale di Geofisica e Vulcanologia, Rome, Italy \\ ${ }^{4}$ Land Development and Engineering Ltd, Gisborne, New Zealand \\ ${ }^{5}$ School of Geography, Environment and Earth Sciences, Victoria University of Wellington, \\ Wellington, New Zealand \\ ${ }^{6}$ Geology Unit, Natural Resources Division, Ministry of Lands and Natural Resources, \\ Nuku'alofa, Tonga \\ *corresponding author: marco.brenna@otago.ac.nz
}

\section{Statement on publication status}

Please note, this manuscript has been peer reviewed and is currently in press in the journal Lithos. Due to the sudden eruption of Hunga volcano in 2022 and publication delays with the journal we have supplied a pre-print through Earth ArXiv. The article was officially accepted by Lithos on December 24th 2022 but has not yet been assigned a DOI. 


\title{
Post-caldera volcanism reveals shallow priming of an intra-ocean arc andesitic caldera: Hunga volcano, Tonga, SW Pacific
}

\author{
Marco Brenna ${ }^{1 *}$, Shane J. Cronin ${ }^{2}$, Ian E.M. Smith ${ }^{2}$, Alessio Pontesilli ${ }^{3}$, Manuela Tost ${ }^{4}$, Simon Barker $^{5}$, Sisi \\ Tonga'onevai ${ }^{6}$, Taaniela Kula ${ }^{6}$, and Rennie Vaiomounga ${ }^{6}$ \\ ${ }^{1}$ Department of Geology, University of Otago, Dunedin, New Zealand \\ ${ }^{2}$ School of Environment, University of Auckland, Auckland, New Zealand \\ ${ }^{3}$ Istituto Nazionale di Geofisica e Vulcanologia, Rome, Italy \\ ${ }^{4}$ Land Development and Engineering Ltd, Gisborne, New Zealand \\ ${ }^{5}$ School of Geography, Environment and Earth Sciences, Victoria University of Wellington, Wellington, New \\ Zealand \\ ${ }^{6}$ Geology Unit, Natural Resources Division, Ministry of Lands and Natural Resources, Nuku'alofa, Tonga \\ *corresponding author: marco.brenna@,otago.ac.nz
}

\begin{abstract}
Intra-oceanic arcs are typically associated with intermediate (andesitic) cone volcanoes. However, caldera volcanoes may also form in these settings from very large eruptions, resulting in sudden changes to the magma reservoir. These reservoirs can then produce either semi-continuous or intermittent low-intensity volcanism between major caldera-producing or caldera-deepening eruptions, providing insights into the post-caldera evolution of the system. Hunga volcano (Kingdom of Tonga, Southwest Pacific) is a large mainly submarine edifice that produced a series of caldera-forming eruptions $\sim 900$ years ago. Since then, numerous smaller-scale subaerial and submarine eruptions occurred, the most recent forming new islands in 2009 and 2014/15. Pyroclastic deposits associated with these latest eruptions have identical (range $\sim 0.1 \mathrm{wt} . \%$ of all major oxides) andesitic composition that overlap with the primitive end of the slightly wider compositional range of the caldera-forming episodes. Texturally simple plagioclase, clinopyroxene and orthopyroxene phenocrysts in pre-, syn- and post-caldera pyroclasts point to a single shallow storage reservoir at 5-8 km depth. Lack of complex zonation indicates that this reservoir is constantly resupplied by low-flux inputs of basaltic andesite magma and is large enough that convective mixing rapidly homogenises new inputs. The reservoir feeds intermittent, low-intensity, post-caldera volcanism with constant andesite composition, driven possibly by magmatic overpressure and "leakage" of gas-rich magma pockets around the edges of the caldera. More primitive and compositionally variable basaltic andesites formed a lava-dominated edifice prior to the caldera-forming event. This suggests a causal link between magma supply dynamics and caldera priming relating to the maturing of the plumbing system and formation of a sustained subvolcanic andesite magma reservoir.
\end{abstract}

Keywords: andesite caldera, mafic ignimbrite; lava; explosive volcanism; Hunga; Tonga; arc volcanism; South Pacific volcanism

\section{Introduction}

Calderas are a feature of long-lived magmatic systems with stable and mature plumbing systems and mainly extensional settings. Caldera volcanoes most commonly occur in continental arc settings and are associated with large magmatic reservoirs that produce evolved (silicic) magmas (Bachmann and Huber, 2016; Hughes and Mahood, 2011; Wilson et al., 1995). In such settings, thicker low-density continental crust leads to long periods of magmatic evolution via assimilation and fractional crystallization (AFC) within a large trans- 
crustal magmatic (mush) system (Ayalew and Ishiwatari, 2011; Deering et al., 2011; Ewart et al., 1977; Huber et al., 2009). Large caldera-forming eruptions are then typically fed from evolved dacite to rhyolite magmas, stored in the shallow crust (Coombs and Gardner, 2001; Vazquez and Reid, 2002). However, smaller calderas, both subaerial and submarine, are also now identified as common features of island arcs, despite the thinner crust (Eichelberger and Izbekov, 2000; Hekinian et al., 2008; Robin et al., 1995; Roobol et al., 1983; Smellie et al., 1998; Toya et al., 2005; Worthington et al., 1999; Wright et al., 2006).

Intra-oceanic calderas also erupt silicic (dacite to rhyolite) magmas, with vast pumice blankets covering the surrounding seafloor (Barker et al., 2013; Barker et al., 2012; Ikegami et al., 2018; Shane and Wright, 2011; Shukuno et al., 2006; Smith et al., 2006; Tamura et al., 2009; Wohletz et al., 1986). In contrast intermediate magma compositions (basaltic andesite to andesite) typically produce stratovolcanoes through the gradual build up of small volume lavas (Caulfield et al., 2012; Firth et al., 2015; Métrich et al., 2011; Nairn et al., 1995; Stern, 1979; Tamura et al., 2019). However, intermediate magmatism can also lead to large-scale caldera formation under the right circumstances (Firth et al., 2015; Robin et al., 1995). Caldera-formation or calderamodification generally occurs during highintensity and large-volume eruptions with a VEI (Volcanic Explosivity Index) $>6$, that are rare in the geological record (Newhall et al., 2018). More frequent volcanism between these events, so-called post-caldera (or intracaldera) eruptions, are typically lower in volume and intensity but provide insights into the mechanisms for magmatic system rejuvenation or recovery towards a possible subsequent caldera-forming eruption.

Compositional overlap has been noted between eruptives from large-volume, highintensity, caldera-forming and calderamodifying events and small-scale intracaldera eruptions at several volcanoes. At
Yasur (Tanna, Vanuatu), within the Yenkahe Caldera, continuous strombolian eruptions over the past $\sim 800$ years have uniform magma composition (Firth et al., 2014), and are associated with the growth of a large shallow magma reservoir driving rapid uplift of the central caldera (Merle et al., 2013). Similar scales and continuity of volcanism are interpreted between two past calderaforming events at c. $43 \mathrm{ka}$ and $>8 \mathrm{ka}$ at this centre (Firth et al., 2021; Firth et al., 2015; Métrich et al., 2011). The eruptive magnitude and frequency at Yasur reflects an overall constant input of compositionally uniform recharging magma (Firth et al., 2014). Largescale eruptions in this case appear to extract magma accumulated over a long period within a central large magma reservoir (Firth et al., 2021). In another case, steady-state magma supply built a large shallow storage system prior to, and between caldera-forming eruptions at Tofua (Tonga), with recharge driving current continuous volcanism (Caulfield et al., 2012). Intra-caldera volcanism may also be intermittent with years/decades-long breaks between events, such as at Rabaul (Papua New Guinea) (Cunningham et al., 2009a; Cunningham et al., 2009b; Nairn et al., 1995).

In all cases of intermediate calderas, the compositional range of post-caldera volcanic products is generally narrower (basaltic andesite/andesite) compared to that of the entire volcano. These compositional relationships suggest that caldera-forming intermediate volcanism in oceanic arc systems is not necessarily caused by sudden arrival of new magma, but follows hundreds to thousands of years of steady supply (and leaking) of magma into a sub-volcanic magmatic reservoir. This is fundamentally different to models generally proposed for continental systems, where tectonics and magma recharge/mixing/buoyancy play a significant role in triggering caldera-forming eruption (Cabaniss et al., 2018; Degruyter et al., 2016; Malfait et al., 2014). A clear relationship between a pre-existing magmatic reservoir driving a calderaforming eruption and post-caldera activity is 
not always apparent. Does the small-scale post-caldera activity signify a magmatic recharge that could ultimately lead to subsequent large caldera-forming eruptions, or does it represent removal of late melts from the post-caldera reservoir (Cunningham et al., 2009a)?

Here we investigate the relationship between pre- syn- and post-caldera magma compositions through a field and chemical investigation of the emergent portion of the mainly submarine Hunga volcano in the central segment of the Tonga Arc. Hunga volcano (Fig. 1) notably formed one of the youngest volcanic islands on Earth in a recent eruption in 2014-2015. In November 2015 we visited the new island for a week to document the nature of the eruption (Colombier et al., 2018) and to assess the context of the recent eruptions within the broader geological history of the volcano (Cronin et al., 2017). We found numerous older deposits of lava and ignimbrite relating to periods of cone formation and caldera collapse. In this paper we assess the compositional relationship between different stages of caldera-related activity at Hunga volcano by examining old-edifice lavas, caldera-related pyroclastics and the most recent lower-intensity post-caldera volcanic products.

\section{Geological Setting}

Hunga volcano is located in the SW Pacific, along the Tonga-Kermadec intra-oceanic arc, which results fron the Pacific Plate subducting beneath the Indo-Australian Plate (Schellart et al., 2006) (Fig. 1a). High-angle convergence, subduction, and slab rollback at the plate boundary have formed a remnant volcanic arc (the Lau-Colville Ridge), a back-arc basin (the Lau Basin-Havre Trench) and the active Tonga - Kermadec Volcanic Arc (Ballance et al., 1999; Smith and Price, 2006) (Fig. 1a) that has a crustal thickness of approximately $20 \mathrm{~km}$ (Contreras-Reyes et al., 2011; Crawford et al., 2003). The central segment of the intra-oceanic Tonga Arc contains $\sim 20$ large volcanic edifices that rise from the sea floor west of the Tonga Ridge to close to or above sea-level (Fig. 1a). At least seven of these volcanoes have erupted since 1770 (Simkin and Siebert, 1994) typically building ephemeral islands of pyroclastic material up to $140 \mathrm{~m}$ above sea level (asl).

Two small uninhabited islands, Hunga Tonga and Hunga Ha'apai, each $\sim 2 \mathrm{~km}$ long and rising up to $114 \mathrm{~m}$ asl, are the summit of the large, mostly submarine, Hunga volcano (Fig. 1b). These islands represent the remnants of a cone destroyed by at least two caldera-forming eruptions (the lastest in 1040-1180 CE), and rise from a submerged caldera identified by recent mapping (Cronin et al., 2017). The two islands mostly consist of lava and scoria cut by dominantly N-S trending dykes of basaltic andesite to andesite composition (Bryan et al., 1972; Fig. 2). On Hunga Ha'apai the topmost sequence of welded and unwelded ignimbrite was deposited by the 1040-1180 CE calderaforming eruption ("welded ignimbrite" in Fig. 2c-e). At least two older sequences of welded and unwelded ignimbrites occur below, beneath paleosols and additional volaniclastic deposits (Fig. 2c-e).

All known historic eruptions at Hunga occurred around the rim of a submerged caldera within the two islands and the southern reef shoal (Cronin et al., 2017) (Fig. 1b). A group of shallow reefs $\sim 3 \mathrm{~km}$ south of Hunga Tonga is the site of eruptive activity in 1912 and 1937 (Bryan et al., 1972). More recently in 1988 a two-day entirely submarine eruption from 2-3 vents aligned SW-NE was also reported near these reefs (Gatliff et al., 1991) (Fig 1b).

\subsection{9 eruptions}

In 2009, a two-month eruption occurred from two vents along the western shore of Hunga Ha'apai (Fig. 1b). These phreatomagmatic eruptions were characterised by numerous base surges and accompanied by ash and steam plumes, which reached heights of $\leq 7.6$ $\mathrm{km}$ asl (Vaughan and Webley, 2010; Venzke et al., 2009). Ambient seismic unrest was 

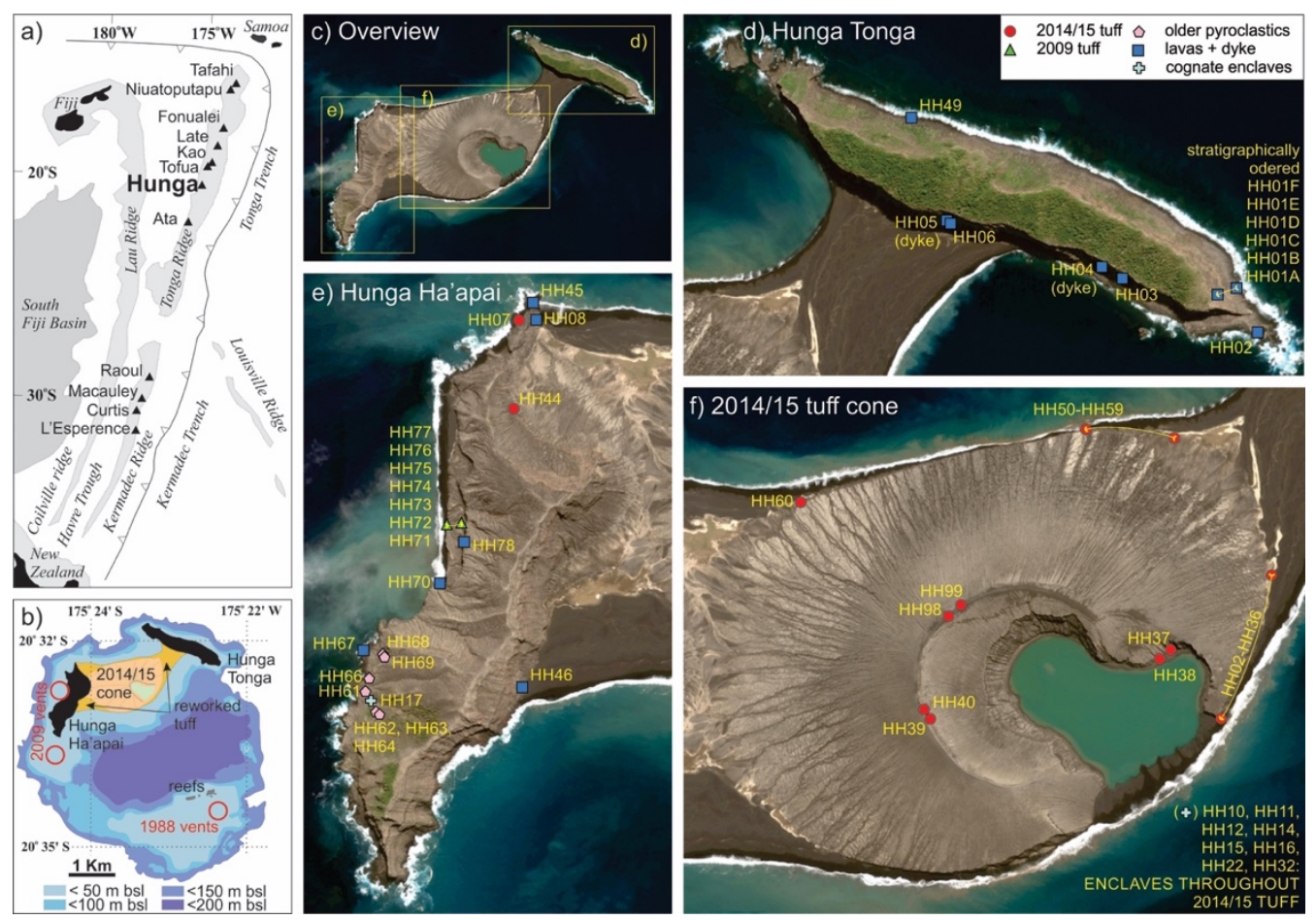

Figure 1. a) Regional geological setting of Hunga volcano in the central portion of the Tongan arc. b) Bathymetry of the summit area and caldera of the Hunga volcano modified from Cronin et al. (2017). c) satellite image of Hunga Tonga-Hunga Ha'apai taken in September 2015. d-f) detailed sampling localities on Hunga Tonga (d), Hunga Ha'apai (e) and the 2014/15 tuff cone (f).

recorded from the site from about three weeks prior to the eruption and indicates that the eruptive activity started several hours prior to the first visual reports (Bohnenstiehl et al., 2013). The young pyroclastic cones were quickly eroded once activity ceased. In November 2015, only a small subaerial remnant of the northern cone was still preserved above sea level on the western site of Hunga Ha'apai (Fig. 1e, 2f).

\section{2. $2014 / 15$ eruptions}

A detailed account of the 2014/15 eruption is presented in the Global Volcanism Program (2015) report. The eruption started on the $19^{\text {th }}$ of December 2014 with tephra jets several hundred $\mathrm{m}$ high. By 6 January 2015, a new island of pyroclastic debris had built up to $\sim 70 \mathrm{~m}$ asl between the islands of Hunga Tonga and Hunga Ha'apai. By 15 January 2015 the new cone had grown to a height of $\sim 80 \mathrm{~m}$ asl and explosive phreatomagmatic eruptions were occurring from three vents aligned roughly NW-SE. Vent migration led to a partial untercutting and collapse of the south-eastern margin of the island. By 24 January 2015 activity ceased, leaving a nearcircular $\sim 120 \mathrm{~m}$ high and $2 \mathrm{~km}$ wide tephra cone connected to Hunga Ha'apai. Subsequent erosion and remobilisation of the pyroclastic deposits formed a tombolo, which connected to Hunga Tonga before 12 April 2015. Wave erosion coming from the south, has subsequently reshaped the cone and reworked the tephra to widen the tombolo (Garvin et al., 2018).

\section{Methods}

Whole rock major element analyses were performed at the School of Environment, University of Auckland (New Zealand) by Xray fluorescence (PANanalytical Axios Xray Fluorescence Spectrometer). Samples were ground in a tungsten carbide ring mill. Loss-on-ignition (LOI) was measured by the weight loss of $\sim 4 \mathrm{~g}$ of sample after heating for 12 hours at $105{ }^{\circ} \mathrm{C}$ and $1,000{ }^{\circ} \mathrm{C}$, respectively. Then, $2 \mathrm{~g}$ of dried sample 

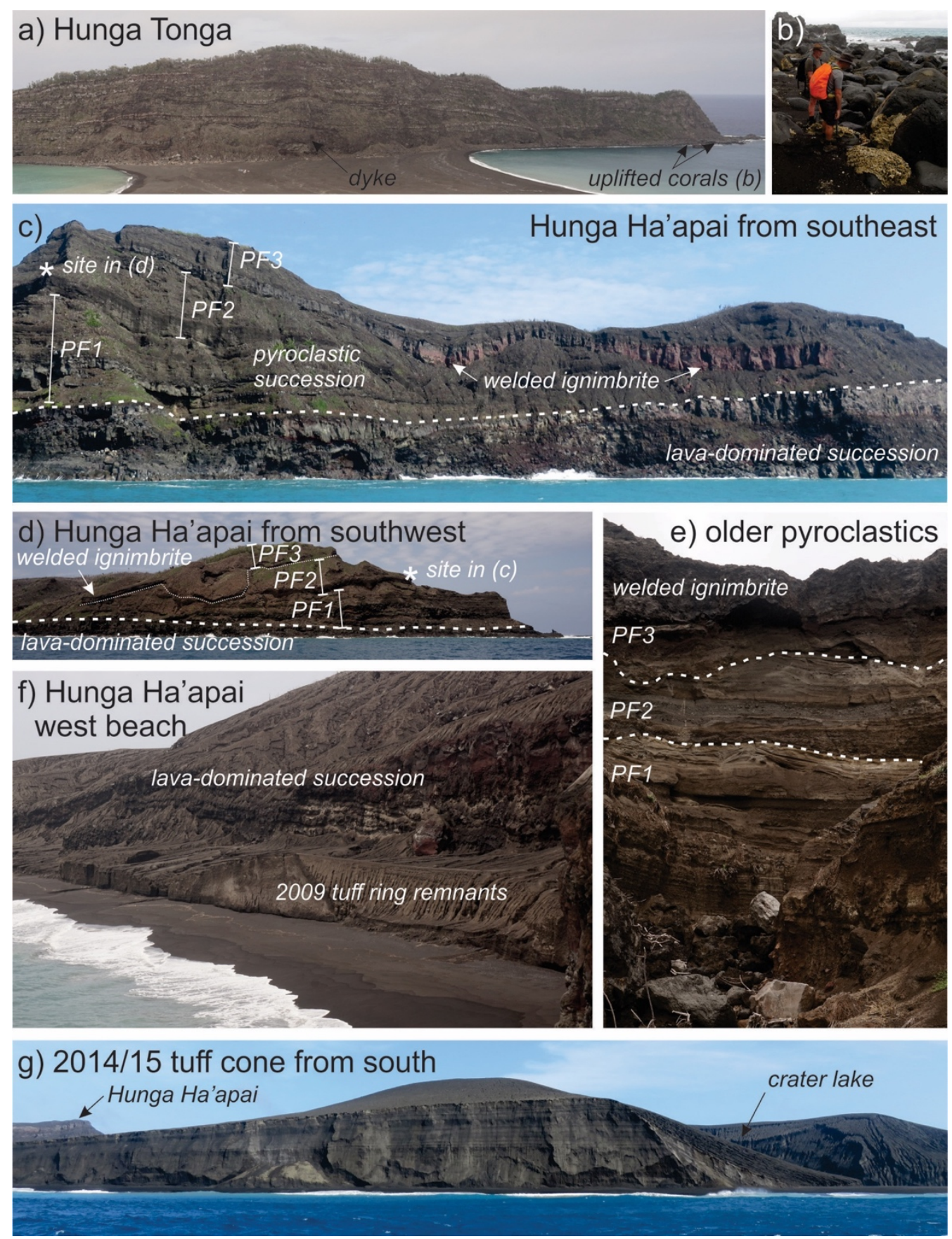

Figure 2. Images of geological features and eruptive stratigraphy on Hunga Tonga and Hunga Ha'apai and the 2014-15 tuff cone. a) Hunga Tonga seen from the southwest at the top of the 201415 tuff cone. b) uplifted corals exposed at the southern end of Hunga Tonga. c) Hunga Ha'apai seen from the southeast showing the thick welded ignimbrite. d) Hunga Ha'apai seen from the southwest. The stars $(*)$ indicates the same site in c) and d). e) detail of the pyroclastic succession associated to caldera formation. At least three packages (PF1, PF2, PF3) are separated by soil horizons and erosional channels. f) Beach on the western side of Hunga Ha'apai where the remnants of the 2009 tuff ring are exposed. Note that on the northern end of Hunga Ha'apai the older sequence is dominated by lavas as opposed to the southern end where the older pyroclastics are thicker. g) The southern eroded side of the 2014/15 tuff cone.

powder were mixed with $6 \mathrm{~g}$ of homogeneous glass bead. The oxide SPECTRACHEM 12-22 flux. The mixture components were measured following was fused in a Pt crucible to obtain a Norrish \& Hutton (1969), with precision 
better than $\pm 2 \%(2 \sigma)$ as determined using repeated analyses of SY-2 and JB-2 standards (Supplementary Data File). The Compton scatter of X-ray tube RhKb1 emission was used to correct for mass attenuation. Theoretical detection limit is $1-2$ ppm and reproducibility is $<5 \%(2 \sigma)$.

Trace elements were analysed by laserablation, inductively-coupled-plasma source, mass-spectrometry (LA-ICP- MS) at the Research School of Earth Sciences, Australian National University in Canberra. The analytical system used an EXIMER ${ }^{\circledR}$ LPX120 laser $(193 \mathrm{~nm})$ connected to an AGILENT $® 7500$ series mass spectrometer. The method follows that of Eggins (2003). LA- ICP-MS analyses were carried out on the same fused glass discs used for XRF; individual discs were glued into multisample mounts and sectioned and polished. Samples were run in batches of 15 using NST612 glass as the calibration standard. Repeat analyses of standard BCR-2 (fused whole rock powder) indicate precision of better than $5 \%(2 \sigma)$ and for most elements, accuracy is within $5 \%$ at the $95 \%$ confidence level consistent with the evaluation of the method by Gao et al., (2002) (Supplementary Data File).

Compositional data on crystals and glass were acquired with the SuperProbe Electron Probe Microanalyzer (EPMA) JEOL JXA 8230 with combined EDS-WDS (five spectrometers with twelve crystals) at Victoria University of Wellington. The accelerating voltage and beam current were $15 \mathrm{kV}$ and $12 \mathrm{nA}$, respectively. The beam size was $10 \mu \mathrm{m}$ (glass analyses) and $2 \mu \mathrm{m}$ (mineral analyses) with a counting time of 20 and $10 \mathrm{~s}$ on peaks and background, respectively. Sodium and potassium were analysed first to minimise alkali migration effects. The precision of the microprobe analyses was measured through analysis of well-characterised synthetic oxides and minerals. Data quality was ensured by measuring the same test materials as unknowns according to the procedure of Iezzi et al. (2014). On the basis of counting statistics, analytical uncertainties relative to repeated analyses indicate that precision was better than 3\% for the major elements of each mineral phase (Supplementary Data File).

Mineral as well as whole-rock major and trace element analyses are reported in the Supplementary Data File.

\section{Results}

\subsection{Petrography and mineral chemistry}

Lava flows and dykes of the older volcanic edifice exposed on Hunga Tonga and Hunga Ha'apai are predominantly porphyritic with phenocryst $(0.5-2 \mathrm{~mm})$ abundances ranging from a few percent up to 30-40 vol.\% (Fig. 2a). No obvious temporal trend is seen in phenocryst abundances up-stratigraphy for the pre-caldera lavas. Plagioclase is the main phenocryst phase with subordinate clinopyroxene and minor orthopyroxene. These often occur as principally monomineralic glomerocrysts, although subophitic intergrowths are also present (Fig. 3a, e). Vesicularity is highly variable from near zero to $30 \%$. Plagioclase crystals have compositions of $\mathrm{An}_{82-95}$ (cores) to $\mathrm{An}_{70-84}$ (rims) (Fig. 4a) and show only minor zonation principally associated with microinclusions (Fig. 3f). Clinopyroxene phenocrysts have compositions of $\mathrm{Wo}_{23}$ ${ }_{29} \mathrm{En}_{46-59} \mathrm{Fs}_{13-31}$ and orthopyroxene phenocrysts have compositions of $\mathrm{Wo}_{5} \mathrm{En}_{60}$ ${ }_{75} \mathrm{Fs}_{20-35}$ (Fig. 4b). The groundmass consists of plagioclase + clinopyroxene + Ca-rich orthopyroxene $+\mathrm{Fe}-\mathrm{Ti}$ oxide.

Numerous cognate enclaves occur within the 2014/15 tephra particles. These are principally plagioclase-dominated cumulates with variable amount of clinopyroxene \pm orthopyroxene \pm pseudomorphed biotite \pm Fe-Ti oxides. Crystals are generally $1-2 \mathrm{~mm}$ in size, although plagioclase up to $4 \mathrm{~mm}$-long occur. Plagioclase has compositions of $\mathrm{An}_{65-}$ 89 and the larger crystals have fine oscillatory zoning related to fluid inclusion-rich growth horizons (Fig. 3b) similar to plagioclase in the older lavas (Fig. 4a). Pyroxene crystals 

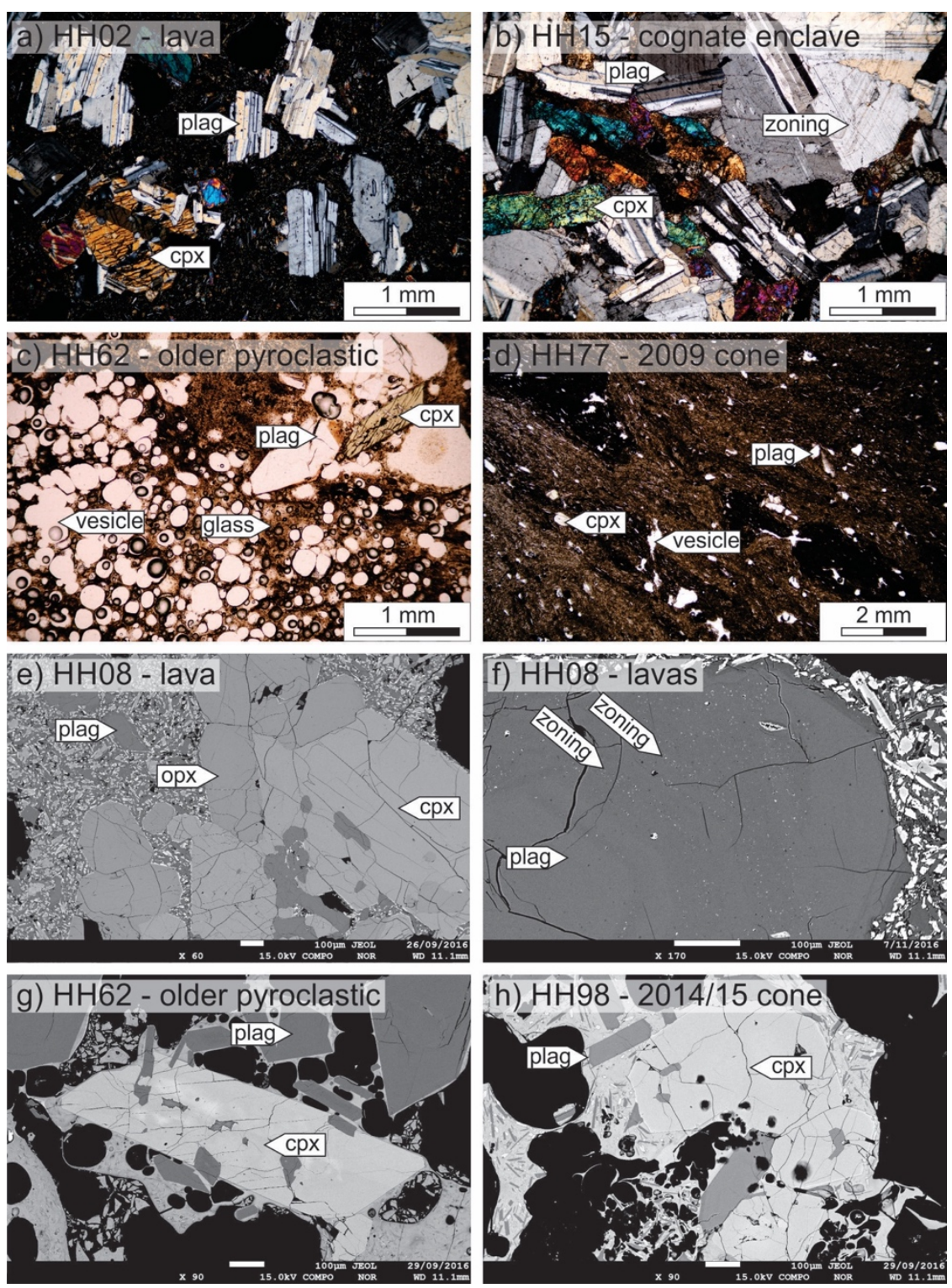

Figure 3. Photomicrographs (a-d) and backscatter electron images (e-h) of the range of lithologies observed. a, e, f) lava flows on Hunga Tonga are dominated by plagioclase, clinopyroxene, orthopyroxene phenocrysts in a clinopyroxene-plagioclase groundmass. b) Xenolith/cognate enclave. Zoning in plagioclase is related to fluid inclusion-rich horizons also seen in the old lavas (f). c, g) Lapilli from pre-historic tuff sequence on Hunga Ha'apai (c, g) and from 2009 and 2014/15 eruption tuff $(\mathrm{d}, \mathrm{h})$ are dominated by clinopyroxene and plagioclase with minor orthopyroxene phenocrysts in a glassy groundmass with clinopyroxene and plagioclase microlites. Note that plagioclase crystals are uniform in $(\mathrm{g})$ and $(\mathrm{h})$.

are variably altered and have compositions of $\mathrm{Wo}_{26-32} \mathrm{En}_{37-56} \mathrm{Fs}_{12-37}$ (clinopyroxene) or $\mathrm{Wo}_{5} \mathrm{En}_{67-70} \mathrm{Fs}_{25-28}$ (orthopyroxene) (Fig. 4b).

Lapilli and bombs from the older pyroclastic deposits as well as within the 2009 and $2014 / 15$ tuff are $20-80 \%$ vesiculated (Colombier et al., 2018) and contain $<5$ vol. \% microphenocrysts $(<1 \mathrm{~mm})$ of mostly tabular plagioclase with minor clinopyroxene \pm orthopyroxene ( $<1$ vol.\%) (Fig. 3c, d, g, h). Plagioclase crystals have lamellar to simple twinning and rarely show complex zoning although they may have thin $(<10 \mu \mathrm{m})$ rims with variable compositions (Fig. 3h). Plagioclase phenocrysts within the 2009 and 2014/15 tephras have dominantly compositions of $\mathrm{An}_{85-93}$ (cores) to $\mathrm{An}_{70-84}$ (rims) similar to those in lava flows (Fig. 4a). In contrast, plagioclase phenocrysts in the 


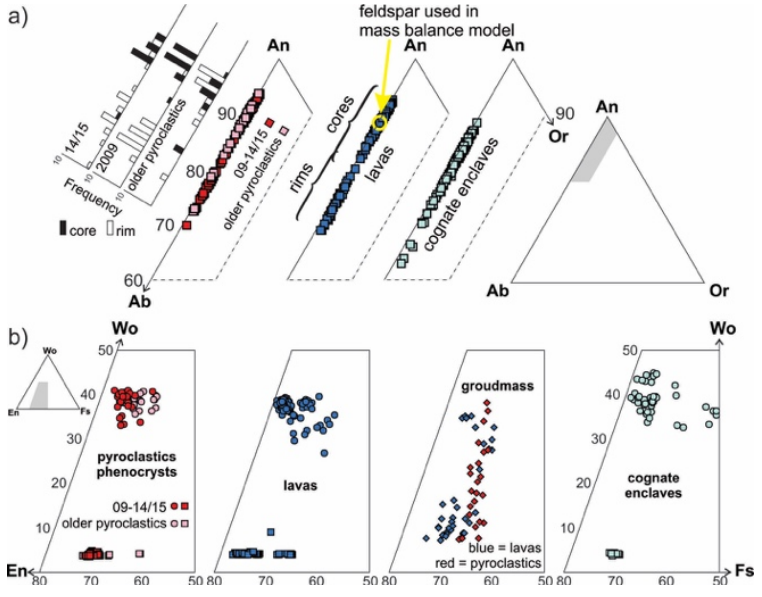

Figure 4. Composition of a) feldspars and b) pyroxenes in Hunga volcanic products.

older pyroclastic deposits related to caldera formation show reverse zoning with rims of An90-94 (Fig. 4a). Plagioclase sometimes occurs as glomerocrystic aggregates with clinopyroxene. The groundmass varies from glassy (sideromelane/tachylite) to consisting of mostly plagioclase microlites. Pyroxenes tend to be more magnesian within the 2009 and 2014/15 eruption products compared to those in the 1040-1180 CE deposits (Fig. 4b) but have overall composition similar to those in older lava flows.

\subsection{Whole-rock geochemistry}

A subset of samples were analysed for whole-rock major and trace elements. These comprise 17 lava flows and dykes from the older edifice, 7 lapilli and bombs from the older pyroclastic deposits including the 1040-1180 CE eruption, 7 cognate enclaves, 7 lapilli and bombs from the 2009 tuff and 27 lapilli and bombs from the 2014/15 cone (Fig. 1, 5).

The overall compositional variation within subaerial parts of Hunga volcano is basaltic andesite to andesitic along a low-K subalkaline trend (Fig. 5a). $\mathrm{TiO}_{2}, \mathrm{FeO}, \mathrm{MnO}$, $\mathrm{Na}_{2} \mathrm{O}, \quad \mathrm{K}_{2} \mathrm{O}$ and $\mathrm{P}_{2} \mathrm{O}_{5}$ are positively correlated with $\mathrm{SiO}_{2}$, whereas $\mathrm{Al}_{2} \mathrm{O}_{3}, \mathrm{MgO}$ and $\mathrm{CaO}$ show a negative correlation with $\mathrm{SiO}_{2}$.

The older edifice lavas and dykes have the widest compositional spectrum ranging at 55-64 wt.\% $\mathrm{SiO}_{2}$, whereas younger tephras each show tightly clustered andesite compositions. Both the 2009 and 2014/15 eruption products have a very limited compositional variation in all major elements within \pm 0.1 wt.\% (Fig. 5). Abundances of $\mathrm{TiO}_{2}, \mathrm{FeO}$ and $\mathrm{P}_{2} \mathrm{O}_{5}$ are very weakly offset from the main chemical trend defined by the older lavas and pyroclastic deposits, but compositions are otherwise within the overall trend for the volcano. Weak chemical trends with stratigraphy are present in the 2014/15 event, whereas only $\mathrm{TiO}_{2}$ has a stratigraphic trend in the 2009 record (Fig. $5 \mathrm{~h})$. The cognate enclaves/xenoliths have lower $\mathrm{SiO}_{2}$ compared to the eruptive products and have high compositional scatter, particularly in $\mathrm{MgO}$ abundance, likely due to mineralogy (Fig. 5e).

Trace elements are consistent with major element characteristics and fractionation assemblages and show depletion in compatible elements (Ni, Cr, Sc, V, Sr) and enrichment in incompatible elements (e.g. $\mathrm{Ba}, \mathrm{Rb}, \mathrm{Zr}$ ) with evolution (increasing $\mathrm{SiO}_{2}$ ). The 2009 and 2014/15 eruption products have relatively more clinopyroxenecompatible elements (e.g. V, given the paucity of Fe-Ti oxides) and relatively less plagioclase-compatible elements (e.g. Sr) compared to the older lavas (Fig. 6a, b). The presence of $\mathrm{Eu} / \mathrm{Eu}^{*}>1$ in the more $\mathrm{SiO}_{2}$-poor lavas and cognate enclaves indicates some degree of plagioclase accumulation (Fig. 6c). The 1040-1180 CE pyroclasts have weak V enrichment comparable to the recent tuff and $\mathrm{Eu} / \mathrm{Eu}^{*}<1$ suggesting some plagioclase fractionation. On a primitive mantle (McDonough and Sun, 1995) normalized diagram, Hunga rocks have relative enrichment of LILE and depletion of HFSE and are light REE depleted with respect to heavy REE (Fig. 6d).

Hunga rocks are more Si-rich than most other Tonga arc volcanoes (Fig. 5a). Ata and Tafahi are dominantly basalt-basaltic andesite and Kao, Late and Tofua are overall basaltic-andesite to andesite. Fonualei is the only subaerial volcano in the arc that has erupted dacite. Additionally, Hunga volcano 

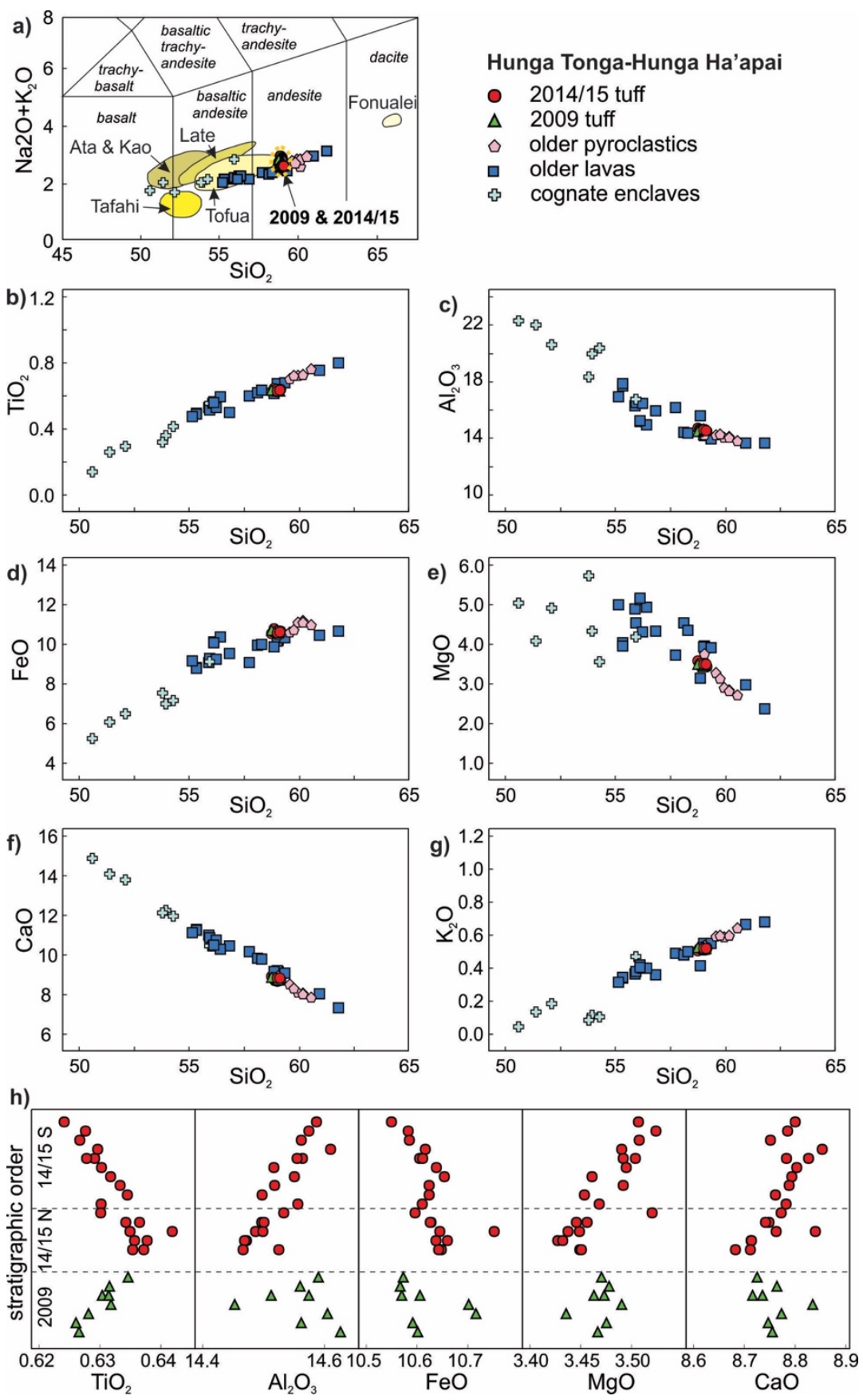

Figure 5. Major element variation of Hunga volcano. a) Total alkali vs silica diagram (Le Maitre et al., 2005) with comparison to other Tonga arc volcanoes: Ata (Turner et al., 1997; Vallier et al., 1985), Tafahi (Ewart, 1976; Ewart et al., 1977; Pearce et al., 2007; Turner et al., 1997; Wendt et al., 1997), Kao (Caulfield et al., 2008), Late (Caulfield et al., 2008; Turner et al., 2012), Tofua (Caulfield et al., 2012; Turner et al., 1997) and Fonualei (Turner et al., 2012). b-g) selected major element variation of Hunga Tonga-Hunga Ha'apai whole-rock samples and glass analyses. h) Stratigraphically ordered whole-rock chemical variability of 2009 and 2014/15 tuff. The 2014/15 samples are divided based on their location on northern or southern portions of the cone as the two sides have limited compositional overlap. Note the minimal compositional range of all 2009 and 2014/15 samples within \pm 0.1 wt. $\%$ for all major oxides.

erupted low-K lavas and tephras, similar to Tafahi and collectively lower $\mathrm{K}$ than other Tonga arc volcanoes. Trace element abundances of Hunga rocks are close to Tofua Volcano (Fig. 6d). Ata Volcano, despite its basaltic nature has enriched trace 
elements than Hunga. Variation patterns and anomalies are nevertheless similar between all Tongan volcanoes (Fig. 6d).
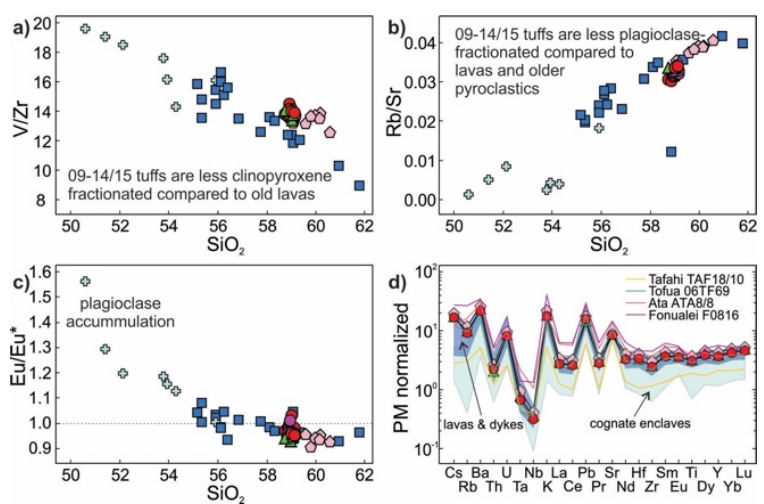

Figure 6. Trace element characteristics of Hunga volcano eruptives. Primitive Mantle (PM) normalizing values in d) are from McDonough and Sun (1995). Sources of data for other Tongan Arc volcanoes are as in Figure 5a.

\section{Reconstruction of the magmatic plumbing system at Hunga}

Despite having a diverse eruptive history, Hunga volcano magma compositions are relatively restricted to intertmediate compositions. Below we describe the magmatic plumbing system at Hunga that gives rise to an andesitic caldera and postcaldera magmatism in an intra-oceanic arc setting.
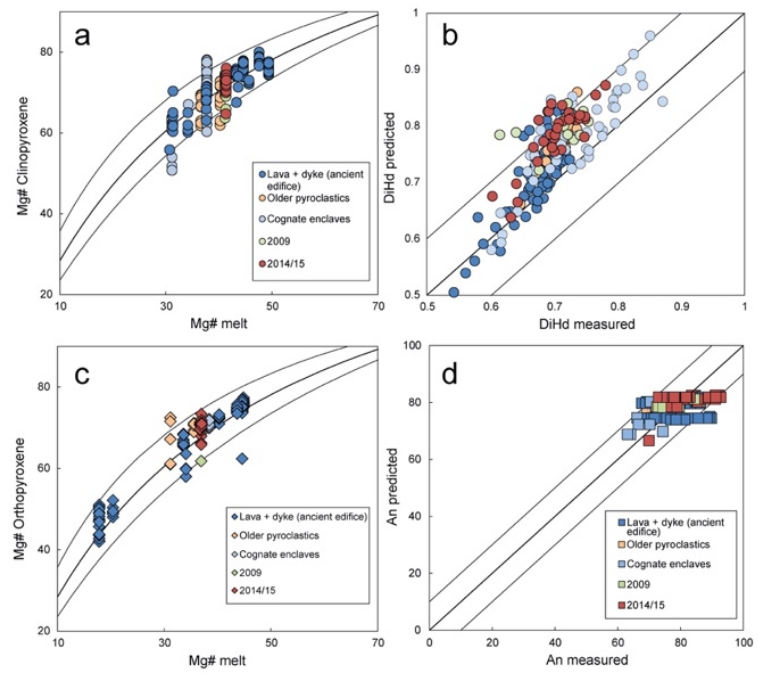

Figure 7. Crystal-melt equilibrium criteria: (a) Clinopyroxene $\mathrm{Mg}-\mathrm{Fe}$ equilibrium plot, $\mathrm{Kd}$ (Fe-Mg) after Putirka (2008). (b) Measured vs. predicted DiHd clinopyroxene components after Mollo et al. (2013). (c) Orthopyroxene $\mathrm{Mg}-\mathrm{Fe}$ equilibrium plot, $\mathrm{Kd}$ (Fe-Mg) after Putirka (2008). (d) Plagioclase measured vs. predicted (Putirka, 2005) anorthite concentration.

\subsection{Thermobarometry}

Crystallization conditions recorded by the magmatic products from Hunga volcano have been calculated based on equilibrium mineral compositions. Given that holocrystalline enclaves are unlikely to represent bulk equilibrium systems (e.g. Ziberna et al., 2017), their crystals have been equilibrated with host rock compositions. In order to estimate crystallization conditions of clinopyroxene, we employed the independent thermometer (error of $\pm 36^{\circ} \mathrm{C}$ ) of Putirka et al. (2003), suited for hydrous andesitic to dacitic magma compositions, and the $T$-dependent barometer (error of \pm 220 $\mathrm{MPa}$; eq. 32a) of Putirka (2008). The crystallization temperatures of orthopyroxene-melt and plagioclase-melt pairs have been calculated on the basis of the $\mathrm{H}_{2} \mathrm{O}$-dependent eq. $28 \mathrm{a}$ and the $\mathrm{H}_{2} \mathrm{O}$ dependent eq. 24a of Putirka (2008; model errors of $\pm 41^{\circ} \mathrm{C}$ and $\pm 36{ }^{\circ} \mathrm{C}$, respectively), by considering melt water contents estimated on the basis of plagioclase-melt pairs. The amount of An in plagioclase is positively correlated either with $T$ or $\mathrm{H}_{2} \mathrm{O}$, thereby it is very difficult to isolate the effect of each variable. To avoid spurious correlation between the two model results, we calculated the activity of An in the melt phase through thermodynamically-derived coefficients from Glazner (1984). Activity of An in the melt phase was used as input parameter in the thermodynamic eq. 28 of Namur et al. (2012), in order to derive the temperature at which the melt was saturated with plagioclase. Once the melt saturation temperature was known, the melt- $\mathrm{H}_{2} \mathrm{O}$ content was determined by applying the hygrometer of Lange et al. (2009) (model 
error \pm 0.32 wt. $\% \mathrm{H}_{2} \mathrm{O}$ ). The attainment of mineral-melt equilibrium was tested via 1) the Fe-Mg exchange between clinopyroxene and melt ${ }^{\text {cpx-melt }} \mathrm{Kd} \mathrm{de}_{\mathrm{Fe}-\mathrm{Mg}}=0.28 \pm 0.08$ ) proposed by Putirka (2008), 2) the model of Mollo et al. (2013) based on the difference $(\Delta)$ between measured vs. predicted diopside + hedenbergite (DiHd) components in clinopyroxene (Mollo and Masotta, 2014), 3) the Fe-Mg exchange between orthopyroxene and melt $\left({ }^{\text {opx-melt }} \mathrm{Kd}_{\mathrm{Fe}-\mathrm{Mg}}=0.29 \pm 0.06\right.$ ) proposed by Putirka (2008), and 4) the model of Putirka (2005) based on the exchange of An between plagioclase and melt (Fig. 7). for crystal rims in lavas and dykes of the ancient edifice $\left(966 \pm 20{ }^{\circ} \mathrm{C}\right)$ and cognate enclaves $\left(933 \pm 3{ }^{\circ} \mathrm{C}\right.$ ) (Fig. 8). These low temperatures could indicate late stage crystallization within the conduit or a shallow crystalline mush lost since caldera formation. Plagioclase mostly equilibrated at lower temperatures than orthopyroxene, but partially overlapping with those of orthopyroxene crystal rims in ancient edifice magmas and cognate enclaves (Fig. 8). Some degree of phase co-saturation during crystallization of Hunga magmas is also indicated by plagioclase inclusions within

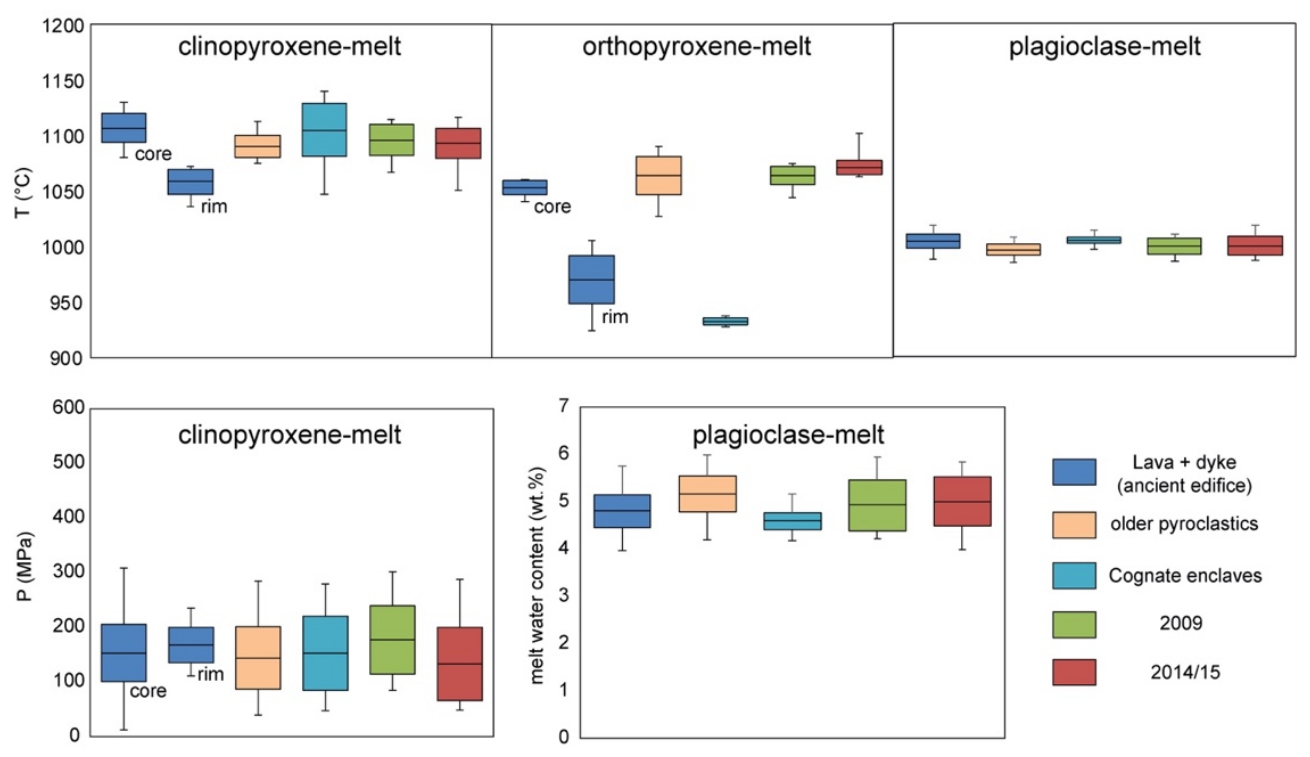

Figure 8: Box-whisker plots of temperature, pressure and melt water content, estimated on the basis of orthopyroxene, clinopyroxene and plagioclase compositions. Central lines inside boxes are defined by the average for each sample group, box outlines are comprised between one standard deviation above and below the average, and the whiskers include all the sample populations. Average and standard deviation values are included in Table 1.

The highest crystallization temperatures are those estimated with clinopyroxene-melt models (1087-1106 $\pm 19{ }^{\circ} \mathrm{C}$, representing the range of mean values and the average standard deviation for all Hunga eruptions). This indicates that clinopyroxene represents the liquidus phase in Hunga magmas. Lower temperatures of $1053 \pm 17^{\circ} \mathrm{C}$ are recorded by clinopyroxene rim compositions in the magmatic products of the ancient edifice (Fig. 8). Orthopyroxene crystallizes at lower temperatures, with orthopyroxene-melt models indicating $1053-1071 \pm 11^{\circ} \mathrm{C}$, except mantles and rims of pyroxene crystals (Fig. 3e, g, h), which can be reconciled with temperature estimates (Table 1) once errors of thermometric models are taken into account (Fig. 8).

The reconstructed temperatures of phenocryst crystallization in Hunga magmas are consistent with experimental results of Firth et al. (2019) for similar Tongan basalts from Late Volcano. Phase equilibria for a hydrous (5 wt.\% initial $\mathrm{H}_{2} \mathrm{O}$ ) Late Volcano basaltic-andesite (similar to the most 
primitive lavas from the old Hunga volcano) (Fig. 5) indicate that crystallization occurred in the shallow crust $(\leq 200 \mathrm{MPa} ;<7 \mathrm{~km})$. This is comparable with results of clinopyroxenebased barometry and plagioclase-based hygrometry, indicating 108-181 $\pm 70 \mathrm{MPa}$ and melt water contents of $4.6-5.1 \pm 0.4$ wt. $\%$, respectively (Fig. 8; Table 1). Residual glass compositions at $950{ }^{\circ} \mathrm{C}$ closely resemble Tongan dacites from Fonualei (Fig. 5), suggesting magma differentiation by crystal fractionation of clinopyroxene, plagioclase and a low-Ca pyroxene in the shallow reservoir (Firth et al., 2019). High melt-water contents of Tongan magmas are also consistent with high $\mathrm{H}_{2} \mathrm{O}$ concentrations in tholeiitic magmas from Late Volcano and neighbouring volcanoes $\left(2.3-4.7\right.$ wt. $\left.\% \mathrm{H}_{2} \mathrm{O}\right)$ (Caulfield et al., 2012; Cooper et al., 2012).

Despite some heterogeneity within the results, depending on the mineral phase and within the limitations of the models used, the general consistent and unimodal $P-T$ estimates across the different eruptive periods record monobaric conditions for the magmatic plumbing system feeding eruptions at Hunga volcano. These results suggest that a main magmatic storage region feeding most recent and pre-historic subaerial eruptions is present at $\sim 2-8 \mathrm{~km}$ beneath the summit of the volcano. Considering that solubility of $\sim 5 \% \mathrm{H}_{2} \mathrm{O}$ in an evolved andesite melt ( $\sim 61$ wt.\% $\left.\quad \mathrm{SiO}_{2}\right)$ requires a minimum pressure of $\sim 150 \mathrm{MPa}$ (Duan, 2014), the depth range for the storage region could be reduced to $\sim 5-8 \mathrm{~km}$. Crystallization of plagioclase and pyroxenes occurs to form cumulate and gabbroic rocks/mushes, which are entrained by erupting magmas. Seismic refraction surveys of the Tonga Ridge slightly north of Hunga volcano have revealed that there is a sudden change in seismic velocity 4 to $5 \mathrm{~km}$ beneath the seafloor (Crawford et al., 2003). Between $\sim 5$ and $10 \mathrm{~km}$ depth seismic velocities of 6 to $6.5 \mathrm{~km} / \mathrm{s}$ are observed and suggested to reflect andesitic compositions in the middle crust. The velocity structure of the Tonga Ridge is strikingly similar to that of the IzuOgasawara arc, where intermediate compositions are also inferred (Suyehiro et al., 1996; Tamura and Tatsumi, 2002). These depths broadly overlap with our estimated storage pressures using mineral barometry $(\sim 200 \mathrm{MPa})$ and highlight the significant volumes of andesite that may reside in this intra-oceanic arc setting. Such rock bodies leftover from intra-oceanic volcano plumbing systems are considered important contributors to continental crustal growth and evolution (Tamura et al., 2016).

\subsection{Pre-caldera and caldera magmatism}

The older Hunga subaerial volcanic edifice was dominated by lava flows with interbedded autobreccias as exposed on Hunga Tonga and Hunga Ha'apai (Fig. 2). Lava compositions range from basaltic andesite to andesite, and their relative stratigraphic position indicates eruptive packages with distinct compositions (Fig. 9). On Hunga Tonga, the lowest exposed lavas are relatively primitive at $\sim 56 \mathrm{wt} . \% \mathrm{SiO}_{2}$. Above these are a set of at least four lava flows with 59-61 wt. $\% \mathrm{SiO}_{2}$ and another set of at least four lava flows with $~ 57-58$ wt.\% $\mathrm{SiO}_{2}$. A direct correlation with lava flows on Hunga Ha'apai is not possible due to lack of exposure, but four lavas underlying the 1040$1180 \mathrm{CE}$ pyroclastic deposits have $\sim 55-56$ wt.\% $\mathrm{SiO}_{2}$. Low-Si lavas have consistently more primitive trace element character, such as higher $\mathrm{V} / \mathrm{Zr}$ and $\mathrm{Eu} / \mathrm{Eu}^{*}$, indicating lesser fractionation of pyroxene and feldspar, whereas high-Si lavas have low $\mathrm{V} / \mathrm{Zr}$ and $\mathrm{Eu} / \mathrm{Eu}^{*}<1$ consistent with fractionation of pyroxene and feldspar (Fig. 6).

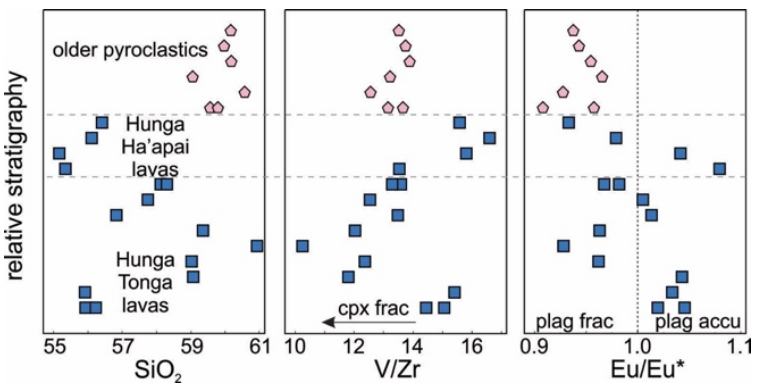

Figure 9. Compositional stratigraphy of lavas and ignimbrite. 
The older lavas are characterised by plagioclase and pyroxene phenocryst compositions analogous to those of caldera and post-caldera deposits. Despite the range in whole-rock compositions, thermobarometric estimates of crystallization conditions in both primitive (HH78) and evolved (HH01C) products are uniform, suggesting magma storage mostly within the upper crust. We tested the fractional crystallization control on the compositional range observed at Hunga volcano using the mass balance (Stormer and Nicholls, 1978) function in the software Petrograph (Petrelli et al., 2005). This is a simplification of the actual fractional crystallization process, because it assumes constant mineral compositions. It nevertheless provides a reliable approximation of crystallization assemblage if the sum of the square of the residuals is $<2$ (Stormer and Nicholls, 1978). In our calculation we used all major oxides, except $\mathrm{P}_{2} \mathrm{O}_{5}$, which was not measured during microprobe analysis of silicate phases. No apatite was observed in our samples. We used the lava with the lowest $\mathrm{SiO}_{2}$ as a parent (sample HH78) and the 1040-1180 CE sample with highest $\mathrm{SiO}_{2}$ as the derivative (HH66). These were both collected on Hunga Ha'apai, but are overall representative of the relatively monotonous variation at Hunga volcano (Fig. 4). Mineral analyses (crystal cores) are from a lava flow on Hunga Ha'apai and representative of all crystal cores analysed for which the variation is relatively restricted (Fig. 3). Results are presented in Table 2. The model produces a best fit result with minimal residuals $(\mathrm{SSR}=0.39)$ for a fractionation assemblage consisting of 26 wt.\% plagioclase, 10 wt.\% clinopyroxene and 8 wt.\% orthopyroxene. The modal mineralogy and composition of the bulk fractionate is similar to that of the cognate enclaves (Fig. 2b), supporting an origin of the latter by accumulation of fractionating crystals. This is supported by the similarity in mineral compositions and subsequently thermo-barometric estimates.

The overall monotonous chemical variation and mineral assemblage in the rocks at
Hunga volcano suggest a mostly monobaric plumbing system, where repeated recharge events inject primitive basaltic andesite magma into the crustal storage area. Processes in the crustal reservoir are dominated by crystallization of plagioclase, orthopyroxene, clinopyroxene as well as minor late stage oxides and biotite. The 1040-1180 CE and earlier explosive eruptions were preceded by eruption of some of the most primitive lavas, but also involved relatively evolved andesite magma (Fig. 9). The presence of both reversely zoned as well as normally zoned clinopyroxene and plagioclase (Fig. 4a) in the pyroclastic products of the caldera-forming events indicates input of a more primitive melt to the magma reservoir, suggesting a possible triggering relationship.

\subsection{Post-caldera magmatic activity}

Compositions of the 2009 and 2014/15 eruption products overlap with the more $\mathrm{SiO}_{2}$-poor end of caldera-forming pyroclastic units (Fig. 5). The whole-rock composition of magma feeding these two recent events only five years apart is essentially analogous (Fig. 5h). Minor differences in the composition of lapilli and bombs distinguish the northern and southern portions of the 2014/15 cone. The northern samples have marginally higher $\mathrm{TiO}_{2}$ but lower $\mathrm{Al}_{2} \mathrm{O}_{3}$, $\mathrm{MgO}$ and $\mathrm{CaO}$ compared to samples from the southern exposures (Fig. 5h).

Small-volume and short-lived eruptions may display a wide spectrum of chemical compositions controlled by magma evolution and ascent processes within the plumbing system (Brenna et al., 2021; McGee et al., 2019). At Hunga volcano, negligible chemical variability in the two recent successive eruptions, five years apart, as well as the homogeneity throughout each eruption implies no differentiation of the melts during ascent to eruption. It is also unlikely that the 2009 and 2014/15 events were fed by deeply derived primitive melts, because they show evolved compositions within the Hunga volcano spectrum (Fig. 5). Crystals in these 
eruptives show no inheritance from deep crustal reservoirs (thermo-barometric estimates are unimodal) and no obvious evidence for mixing/resorption. Therefore, the 2009 and 2014/15 Hunga volcano eruptions are likely fed from a shallow crustal/subvolcanic $(5-8 \mathrm{~km})$ reservoir.

Pyroxene crystals tend to be more magnesian in the 2009 and $2014 / 15$ products compared to those of the older pyroclastics (Fig. 4b). This implies that the recent events are not simply sourced from residual cooling and crystallization of a post-caldera reservoir, but that fresh magma input into the system has occurred. The simple crystal textures imply that magma recharge occurred at a slow and steady rate, or that recharging magmas entered a large volume and actively convecting magma reservoir. Convective mixing within the reservoir enables extraction and eruption of constant andesitic compositions (Fig. 10). This is in contrast to systems where intra-caldera eruptions are dominantly basaltic and directly derived from deeper portion of the plumbing system (Stern, 1979) or where mixing and mingling is obvious due to the presence of complex mineral zoning and enclaves (Fabbro et al., 2020).

The 2009 and 2014/15 eruptions therefore represent minor extraction (i.e., leaking) events of relatively small and homogeneous magma batches from the convecting subvolcanic reservoir. Dyking and preferred locations of magma ascent is facilitated by fracturing and structural weaknesses and a modified stress-field around the caldera rim after caldera forming eruptions (Corbi et al., 2015). This scenario for Hunga volcano is consistent with other intra-oceanic arc steady-state andesitic caldera systems, such as at Yasur (Firth et al., 2014) or Tofua (Caulfield et al., 2012).

\subsection{Implications for processes controlling caldera onset}

Our study presents a view of the magmatic system of an intra-oceanic arc volcano before and after a caldera-forming eruption (or

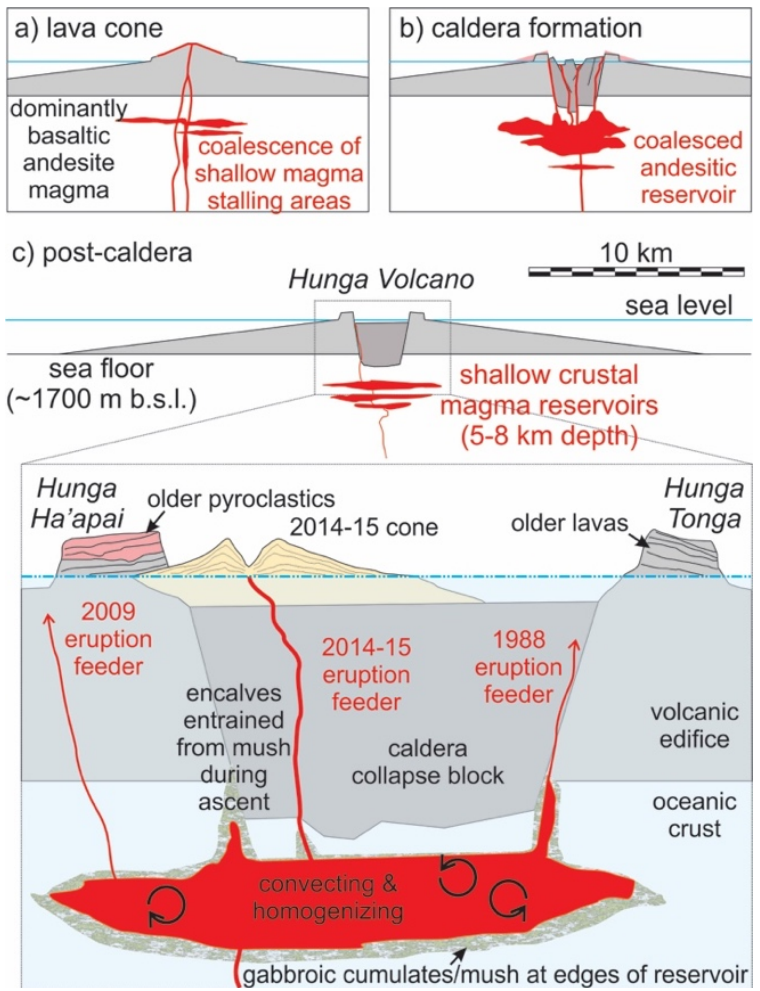

Figure 10. Conceptual model of Hunga volcano plumbing geometry. See text for details of the sequence of events and maturity of the plumbing system.

series of eruptions). Before the cataclysmic event, the system was dominated by lava effusion (Fig. 2, 10a). Erupted compositions ranged from basaltic andesite to andesite resulting from $>40 \%$ fractional crystallization of plagioclase and pyroxenes. The compositional evolution occurred mostly within the upper few $\mathrm{km}$ of the crust. Lack of complex zonation in crystals within lavas and enclaves implies that separate, monotonous, individual magma batches fed lava effusion events, rather than a common zoned magmatic reservoir. Amalgamation of these over time would have nevertheless led to the growth of shallow magma storage areas (Biggs and Annen, 2019). Formation of a large magma reservoir fed by continuous injection of basaltic andesite magma within the shallow crust likely pre-conditioned the system for the caldera-forming eruption (Aizawa et al., 2006; Sparks et al., 2019) (Fig. 10b). The magma system of Hunga volcano matured with repeated injections up to the initiation of the caldera forming event sequence (Fig. 9). The nearby emergent 
volcanoes in the Tonga Arc, Ata, Kao and Late (Fig. 1a), have compositions ranging from basalt to basaltic andesite (Fig. 5a), and have not experienced caldera collapse. Tofua and Fonualei (Fig. 1a) have had previous caldera collapse and their compositions range up to andesite and dacite (Fig. 5a). We suggest that the maturity of a magmatic system represents a driving factor for occurrence of caldera collapse in intraoceanic arc volcanoes. Based on their relative degree of chemical evolution, Late volcano may be the next site of caldera collapse within the Tonga Arc if similar preeruptive processes were to occur. However, geophysical measurements of the magma reservoir would be needed to confirm this hypothesis.

The magma feeding process is likely ongoing in the post-caldera period at Hunga volcano, with recent eruptions (e.g., historical ones) representing surface "leaks" of magma, with part of the supply going into the gradual (re)building of a shallow reservoir (Fig. 10c). Evidence for recent shallow magma reservoir growth and caldera resurgence is shown by bathymetric evidence of large shallow portions in the SE caldera (Fig. 1 and Cronin et al., 2017), along with recently uplifted shore-platforms and fresh/intracate coral along the Hunga Tonga shoreline (Fig. 2b). These fragile coral colonies are in growth position on a high-energy coast, thus they must have been exposed for only months to years. Their position at and above current high-tide mark indicates at least $10 \mathrm{~m}$ of recent post-caldera uplift. All these lines of evidence points to a shallow magmatic system that is actively growing and will continue to produce eruptions of variable magnitude and style.

\section{Conclusions}

Extensive sampling of the subaerial portion of the Hunga volcanic edifice, including products from 2009 and 2014/15 Surtseyanstyle eruptions, reveal a currently monobaric, steady-state magmatic plumbing system.
Eruptions of lava building the older edifice have variably basaltic andesite to andesite composition, and culminate in the 1040-1180 $\mathrm{CE}$ andesitic welded ignimbrites of a caldera forming event. This was followed by intermittent post-caldera volcanism. The latest two events, in 2009 and 2014/15 built phreatomagmatic cones/rings along the rim of the caldera and have consistently homogeneous andesite composition. The relatively simple crystal cargo of both lavas, as well as old and young pyroclastics, provide evidence for magmatic evolution occurring within a single magmatic storage area within the shallow crust $(5-8 \mathrm{~km})$. Lack of complex crystal zoning patterns in both volcanic products and mush/enclaves, as well as the constant composition of post-caldera eruptions, support a relative steady-state supply of primitive magma within a homogenizing reservoir. Recent intracaldera uplift is indicated by a broad shallow platform on the southern caldera and fragile, freshly uplifted coral heads on the calderainside shore of Hunga Tonga. This, together with the regular historic eruptions indicate that the magmatic system beneath Hunga is gradually growing and evolving from repeated recharge events into a relatively homogeneous andesitic reservoir. Similar trends in magma chemistry should be taken into account at other Tongan volcanoes where large caldera-forming eruptions could occur in the future.

\section{Acknowledgements}

This research was funded by the Faculty Research Development Fund, The University of Auckland to MB and SJC. We are grateful for financial and logistic support from ICON Films, Bristol, UK. We are especially grateful for the help and company of Lucy Meadows and Alex Holden, ICON Films, UK, during the field studies. We would further like to thank the Pacific Rose crew from Pacific Sunrise fishing for transport and logistical support. Ian Schipper assisted EPMA data collection. We thank two anonymous reviewers for helpful comments, and Michael Roden for editorial handling. 


\section{References}

Aizawa, K., Acocella, V., Yoshida, T., 2006. How the development of magma chambers affects collapse calderas: insights from an overview. Geological Society, London, Special Publications 269, 65-81.

Ayalew, D., Ishiwatari, A., 2011. Comparison of rhyolites from continental rift, continental arc and oceanic island arc: Implication for the mechanism of silicic magma generation. Island arc 20, 78-93.

Bachmann, O., Huber, C., 2016. Silicic magma reservoirs in the Earth's crust. American Mineralogist 101, 2377-2404.

Ballance, P.F., Ablaev, A.G., Pushchin, I.K., Pletnev, S.P., Birylina, M.G., Itaya, T., Follas, H.A., Gibson, G.W., 1999. Morphology and history of the Kermadec trench-arc-backarc basin-remnant arc system at 30 to $32 \mathrm{~S}$ : geophysical profile, microfossil and $\mathrm{K}-\mathrm{Ar}$ data. Marine Geology 159, 35-62.

Barker, S., Wilson, C., Baker, J., Millet, M.-A., Rotella, M., Wright, I., Wysoczanski, R., 2013. Geochemistry and petrogenesis of silicic magmas in the intra-oceanic Kermadec arc. Journal of Petrology 54, 351-391.

Barker, S.J., Rotella, M.D., Wilson, C.J., Wright, I.C., Wysoczanski, R.J., 2012. Contrasting pyroclast density spectra from subaerial and submarine silicic eruptions in the Kermadec arc: implications for eruption processes and dredge sampling. Bulletin of volcanology 74, 1425-1443.

Biggs, J., Annen, C., 2019. The lateral growth and coalesence of magma systems. Philosophical Transactions of the Royal Society A 377, 20180005. Bohnenstiehl, D.R., Dziak, R.P., Matsumoto, H., Lau, T.-K.A., 2013. Underwater acoustic records from the March 2009 eruption of Hunga Ha'apai-Hunga Tonga volcano in the Kingdom of Tonga. Journal of Volcanology and Geothermal Research 249, 12-24. Brenna, M., Ubide, T., Nichols, A.R., Mollo, S., Pontesilli, A., 2021. Anatomy of Intraplate Monogenetic Alkaline Basaltic Magmatism: Clues From Magma, Crystals, and Glass. Crustal Magmatic System Evolution: Anatomy, Architecture, and Physico-Chemical Processes, 79-103.

Bryan, W., Stice, G., Ewart, A., 1972. Geology, petrography, and geochemistry of the volcanic islands of Tonga. Journal of geophysical research 77, 15661585.

Cabaniss, H.E., Gregg, P.M., Grosfils, E.B., 2018. The role of tectonic stress in triggering large silicic caldera eruptions. Geophysical Research Letters 45, 3889-3895.

Caulfield, J., Turner, S., Dosseto, A., Pearson, N., Beier, C., 2008. Source depletion and extent of melting in the Tongan sub-arc mantle. Earth and Planetary Science Letters 273, 279-288.

Caulfield, J., Turner, S.P., Smith, I., Cooper, L., Jenner, G.A., 2012. Magma evolution in the primitive, intra-oceanic Tonga arc: petrogenesis of basaltic andesites at Tofua volcano. Journal of Petrology 53, 1197-1230.

Colombier, M., Scheu, B., Wadsworth, F., Cronin, S., Vasseur, J., Dobson, K., Hess, K.U., Tost, M., Yilmaz, T., Cimarelli, C., 2018. Vesiculation and Quenching During Surtseyan Eruptions at Hunga Tonga-Hunga Ha'apai Volcano, Tonga. Journal of Geophysical Research: Solid Earth 123, 3762-3779. Contreras-Reyes, E., Grevemeyer, I., Watts, A.B., Flueh, E.R., Peirce, C., Moeller, S., Papenberg, C., 2011. Deep seismic structure of the Tonga subduction zone: Implications for mantle hydration, tectonic erosion, and arc magmatism. Journal of Geophysical Research: Solid Earth 116.

Coombs, M.L., Gardner, J.E., 2001. Shallow-storage conditions for the rhyolite of the 1912 eruption at Novarupta, Alaska. Geology 29, 775-778.

Cooper, L.B., Ruscitto, D.M., Plank, T., Wallace, P.J., Syracuse, E.M., Manning, C.E., 2012. Global variations in $\mathrm{H} 2 \mathrm{O} / \mathrm{Ce}: 1$. Slab surface temperatures beneath volcanic arcs. Geochemistry, Geophysics, Geosystems 13.

Corbi, F., Rivalta, E., Pinel, V., Maccaferri, F., Bagnardi, M., Acocella, V., 2015. How caldera collapse shapes the shallow emplacement and transfer of magma in active volcanoes. Earth and Planetary Science Letters 431, 287-293.

Crawford, W.C., Hildebrand, J.A., Dorman, L.M., Webb, S.C., Wiens, D.A., 2003. Tonga Ridge and Lau Basin crustal structure from seismic refraction data. Journal of Geophysical Research: Solid Earth 108.

Cronin, S., Brenna, M., Smith, I., Barker, S., Tost, M., Ford, M., Tonga'onevai, S., Kula, T., Vaiomounga, R., 2017. New volcanic island unveils explosive past. Eos, Transactions American Geophysical Union 98, 18-23.

Cunningham, H., Turner, S., Dosseto, A., Patia, H., Eggins, S.M., Arculus, R., 2009a. Temporal variations in U-series disequilibria in an active caldera, Rabaul, Papua New Guinea. Journal of Petrology 50, 507-529.

Cunningham, H., Turner, S., Patia, H., Wysoczanski, R., Nichols, A., Eggins, S., Dosseto, A., 2009b. $(210 \mathrm{~Pb} / 226 \mathrm{Ra})$ variations during the 1994-2001 intracaldera volcanism at Rabaul Caldera. Journal of volcanology and geothermal research 184, 416-426.

Deering, C., Bachmann, O., Dufek, J., Gravley, D., 2011. Rift-related transition from andesite to rhyolite volcanism in the Taupo Volcanic Zone (New Zealand) controlled by crystal-melt dynamics in mush zones with variable mineral assemblages. Journal of Petrology 52, 2243-2263.

Degruyter, W., Huber, C., Bachmann, O., Cooper, K.M., Kent, A.J., 2016. Magma reservoir response to transient recharge events: The case of Santorini volcano (Greece). Geology 44, 23-26. 
Duan, X., 2014. A general model for predicting the solubility behavior of $\mathrm{H} 2 \mathrm{O}-\mathrm{CO} 2$ fluids in silicate melts over a wide range of pressure, temperature and compositions. Geochimica et Cosmochimica Acta 125, 582-609.

Eggins, S.M., 2003. Laser ablation ICP-MS analysis of geological materials prepared as lithium borate glasses. Geostandards Newsletter 27, 147-162.

Eichelberger, J.C., Izbekov, P.E., 2000. Eruption of andesite triggered by dyke injection: contrasting cases at Karymsky Volcano, Kamchatka and Mt Katmai, Alaska. Philosophical Transactions of the Royal Society of London. Series A: Mathematical, Physical and Engineering Sciences 358, 1465-1485. Ewart, A., 1976. A petrological study of the younger Tongan andesites and dacites, and the olivine tholeiites of Niua Fo'ou Island, SW Pacific. Contributions to Mineralogy and Petrology 58, 1-21. Ewart, A., Brothers, R., Mateen, A., 1977. An outline of the geology and geochemistry, and the possible petrogenetic evolution of the volcanic rocks of the Tonga-Kermadec-New Zealand island arc. Journal of volcanology and geothermal research 2, 205-250.

Fabbro, G.N., McKee, C.O., Sindang, M.E., Eggins, S., de Maisonneuve, C.B., 2020. Variable mafic recharge across a caldera cycle at Rabaul, Papua New Guinea. Journal of Volcanology and Geothermal Research 393, 106810.

Firth, C., Adam, J., Turner, S., Rushmer, T., Brens, R., Green, T.H., Erdmann, S., O'Neill, H., 2019. Experimental constraints on the differentiation of low-alkali magmas beneath the Tonga arc: Implications for the origin of arc tholeiites. Lithos 344, 440-451.

Firth, C., Turner, S., Handley, H., Turner, M., Cronin, S., Girard, G., Smith, I., 2021. Rapid magmatic processes drive persistently active volcanism. Lithos 380, 105868.

Firth, C.W., Cronin, S.J., Turner, S.P., Handley, H.K., Gaildry, C., Smith, I., 2015. Dynamics and preeruptive conditions of catastrophic, ignimbriteproducing eruptions from the Yenkahe Caldera, Vanuatu. Journal of Volcanology and Geothermal Research 308, 39-60.

Firth, C.W., Handley, H.K., Cronin, S.J., Turner, S.P., 2014. The eruptive history and chemical stratigraphy of a post-caldera, steady-state volcano: Yasur, Vanuatu. Bulletin of Volcanology 76, 837.

Gao, S., Liu, X., Yuan, H., Hattendorf, B., Günther, D., Chen, L., Hu, S., 2002. Determination of forty two major and trace elements in USGS and NIST SRM glasses by laser ablation-inductively coupled plasmamass spectrometry. Geostandards Newsletter 26, 181-196.

Garvin, J.B., Slayback, D.A., Ferrini, V., Frawley, J., Giguere, C., Asrar, G.R., Andersen, K., 2018. Monitoring and Modeling the Rapid Evolution of Earth's Newest Volcanic Island: Hunga Tonga Hunga Ha'apai (Tonga) Using High Spatial Resolution
Satellite Observations. Geophysical research letters 45, 3445-3452.

Gatliff, R.W., Helu, S., Singh, R., 1991. Annual report of The World Volcanic Eruptions in 1988. Bulletin of Volcanology 53, 1-108.

Glazner, A.F., 1984. Activities of olivine and plagioclase components in silicate melts and their application to geothermometry. Contributions to Mineralogy and Petrology 88, 260-268.

Global Volcanism Program, 2015. Report on Hunga Tonga-Hunga Ha'apai (Tonga), in: Wunderman, R. (Ed.), Bulletin of the Global Volcanism Network, 40:1. Smithsonian Institution. https://doi.org/10.5479/si.GVP.BGVN201501243040.

Hekinian, R., Mühe, R., Worthington, T.J., Stoffers, P., 2008. Geology of a submarine volcanic caldera in the Tonga Arc: Dive results. Journal of Volcanology and Geothermal Research 176, 571-582.

Huber, C., Bachmann, O., Manga, M., 2009. Homogenization processes in silicic magma chambers by stirring and mushification (latent heat buffering). Earth and Planetary Science Letters 283, 38-47.

Hughes, G.R., Mahood, G.A., 2011. Silicic calderas in arc settings: Characteristics, distribution, and tectonic controls. Bulletin 123, 1577-1595.

Iezzi, G., Mollo, S., Shahini, E., Cavallo, A., Scarlato, P., 2014. The cooling kinetics of plagioclase feldspar as revealed by electron-microprobe mapping. American Mineralogist 99, 898-907.

Ikegami, F., McPhie, J., Carey, R., Mundana, R., Soule, A., Jutzeler, M., 2018. The eruption of submarine rhyolite lavas and domes in the deep ocean-Havre 2012, Kermadec Arc. Frontiers in Earth Science 6, 147.

Lange, R.A., Frey, H.M., Hector, J., 2009. A thermodynamic model for the plagioclase-liquid hygrometer/thermometer. American Mineralogist 94, 494-506.

Le Maitre, R.W., Streckeisen, A., Zanettin, B., Le Bas, M., Bonin, B., Bateman, P., 2005. Igneous rocks: a classification and glossary of terms: recommendations of the International Union of Geological Sciences Subcommission on the Systematics of Igneous Rocks. Cambridge University Press.

Malfait, W.J., Seifert, R., Petitgirard, S., Perrillat, J.P., Mezouar, M., Ota, T., Nakamura, E., Lerch, P., Sanchez-Valle, C., 2014. Supervolcano eruptions driven by melt buoyancy in large silicic magma chambers. Nature Geoscience 7, 122-125.

McDonough, W.F., Sun, S.-S., 1995. The composition of the Earth. Chemical geology 120, 223-253.

McGee, L., Morgado, E., Brahm, R., Parada, M.-Á., Vinet, N., Lara, L.E., Flores, A., Turner, M., Handley, H., Nowell, G., 2019. Stratigraphically controlled sampling captures the onset of highly fluid-fluxed melting at San Jorge volcano, Southern Volcanic 
Zone, Chile. Contributions to Mineralogy and Petrology 174, 102.

Merle, O., Brothelande, E., Lénat, J.-F., Bachèlery, P., Garaébiti, E., 2013. A structural outline of the Yenkahe volcanic resurgent dome (Tanna Island, Vanuatu Arc, South Pacific). Journal of volcanology and geothermal research 268, 64-72.

Métrich, N., Allard, P., Aiuppa, A., Bani, P., Bertagnini, A., Shinohara, H., Parello, F., Di Muro, A., Garaebiti, E., Belhadj, O., 2011. Magma and volatile supply to post-collapse volcanism and block resurgence in Siwi Caldera (Tanna Island, Vanuatu Arc). Journal of Petrology 52, 1077-1105.

Mollo, S., Masotta, M., 2014. Optimizing preeruptive temperature estimates in thermally and chemically zoned magma chambers. Chemical Geology 368, 97-103.

Mollo, S., Putirka, K., Misiti, V., Soligo, M., Scarlato, P., 2013. A new test for equilibrium based on clinopyroxene-melt pairs: clues on the solidification temperatures of Etnean alkaline melts at post-eruptive conditions. Chemical Geology 352, 92-100.

Nairn, I., McKee, C., Talai, B., Wood, C., 1995. Geology and eruptive history of the Rabaul Caldera area, Papua New Guinea. Journal of Volcanology and Geothermal Research 69, 255-284.

Namur, O., Charlier, B., Toplis, M.J., Vander Auwera, J., 2012. Prediction of plagioclase-melt equilibria in anhydrous silicate melts at 1-atm. Contributions to Mineralogy and Petrology 163, 133150.

Newhall, C., Self, S., Robock, A., 2018. Anticipating future Volcanic Explosivity Index (VEI) 7 eruptions and their chilling impacts. Geosphere 14, 572-603.

Norrish, K., Hutton, J.T., 1969. An accurate X-ray spectrographic method for the analysis of a wide range of geological samples. Geochimica et cosmochimica acta 33, 431-453.

Pearce, J.A., Kempton, P., Gill, J., 2007. Hf-Nd evidence for the origin and distribution of mantle domains in the SW Pacific. Earth and Planetary Science Letters 260, 98-114.

Petrelli, M., Poli, G., Perugini, D., Peccerillo, A., 2005. PetroGraph: a new software to visualize, model, and present geochemical data in igneous petrology. Geochemistry, Geophysics, Geosystems 6. Putirka, K.D., 2005. Igneous thermometers and barometers based on plagioclase + liquid equilibria: Tests of some existing models and new calibrations. American Mineralogist 90, 336-346.

Putirka, K.D., 2008. Thermometers and barometers for volcanic systems. Reviews in mineralogy and geochemistry 69, 61-120.

Putirka, K.D., Mikaelian, H., Ryerson, F., Shaw, H., 2003. New clinopyroxene-liquid thermobarometers for mafic, evolved, and volatile-bearing lava compositions, with applications to lavas from Tibet and the Snake River Plain, Idaho. American Mineralogist 88, 1542-1554.
Robin, C., Eissen, J.P., Monzier, M., 1995. Mafic pyroclastic flows at Santa Maria (Gaua) volcano, Vanuatu: the caldera formation problem in mainly mafic island arc volcanoes. Terra Nova 7, 436-443.

Roobol, M., Wright, J., Smith, A., 1983. Calderas or gravity-slide structures in the Lesser Antilles island arc? Journal of Volcanology and Geothermal Research 19, 121-134.

Schellart, W., Lister, G., Toy, V., 2006. A Late Cretaceous and Cenozoic reconstruction of the Southwest Pacific region: tectonics controlled by subduction and slab rollback processes. EarthScience Reviews 76, 191-233.

Shane, P., Wright, I.C., 2011. Late Quaternary tephra layers around Raoul and Macauley Islands, Kermadec Arc: implications for volcanic sources, explosive volcanism and tephrochronology. Journal of Quaternary Science 26, 422-432.

Shukuno, H., Tamura, Y., Tani, K., Chang, Q., Suzuki, T., Fiske, R., 2006. Origin of silicic magmas and the compositional gap at Sumisu submarine caldera, Izu-Bonin arc, Japan. Journal of Volcanology and Geothermal Research 156, 187-216. Simkin, T., Siebert, L., 1994. Volcanoes of the world - a regional directory, gazeteer and chronology of volcanism during the last 10,000 years, 2nd edn. Global Volcanism Program. Smithsonian Institution, Washington, DC 348.

Smellie, J., Morris, P., Leat, P., Turner, D., Houghton, D., 1998. Submarine caldera and other volcanic observations in Southern Thule, South Sandwich Islands. Antarctic Science 10, 171-172.

Smith, I.E., Price, R.C., 2006. The Tonga-Kermadec arc and Havre-Lau back-arc system: their role in the development of tectonic and magmatic models for the western Pacific. Journal of volcanology and geothermal research 156, 315-331.

Smith, I.E.M., Worthington, T.J., Price, R.C., Stewart, R.B., Maas, R., 2006. Petrogenesis of dacite in an oceanic subduction environment: Raoul Island, Kermadec arc. Journal of Volcanology and Geothermal Research 156, 252-265.

Sparks, R., Annen, C., Blundy, J., Cashman, K., Rust, A., Jackson, M., 2019. Formation and dynamics of magma reservoirs. Philosophical Transactions of the Royal society A 377, 20180019.

Stern, R.J., 1979. On the origin of andesite in the northern Mariana island arc: Implications from Agrigan. Contributions to Mineralogy and Petrology 68, 207-219.

Stormer, J.C., Nicholls, J., 1978. XLFRAC: a program for the interactive testing of magmatic differentiation models. Computers \& Geosciences 4, 143-159.

Suyehiro, K., Takahashi, N., Ariie, Y., Yokoi, Y., Hino, R., Shinohara, M., Kanazawa, T., Hirata, N., Tokuyama, H., Taira, A., 1996. Continental crust, crustal underplating, and low-Q upper mantle beneath an oceanic island arc. Science 272, 390-392. 
Tamura, Y., Gill, J.B., Tollstrup, D., Kawabata, H., Shukuno, H., Chang, Q., Miyazaki, T., Takahashi, T., Hirahara, Y., Kodaira, S., 2009. Silicic magmas in the Izu-Bonin oceanic arc and implications for crustal evolution. Journal of Petrology 50, 685-723.

Tamura, Y., Ishizuka, O., Sato, T., Nichols, A.R., 2019. Nishinoshima volcano in the Ogasawara Arc: New continent from the ocean? Island Arc 28, e12285.

Tamura, Y., Sato, T., Fujiwara, T., Kodaira, S., Nichols, A., 2016. Advent of continents: A new hypothesis. Scientific Reports 6, 1-12.

Tamura, Y., Tatsumi, Y., 2002. Remelting of an andesitic crust as a possible origin for rhyolitic magma in oceanic arcs: an example from the IzuBonin arc. Journal of Petrology 43, 1029-1047.

Toya, N., Ban, M., Shinjo, R., 2005. Petrology of Aoso volcano, northeast Japan arc: temporal variation of the magma feeding system and nature of low-K amphibole andesite in the Aoso-Osore volcanic zone. Contributions to Mineralogy and Petrology 148, 566581.

Turner, S., Caulfield, J., Rushmer, T., Turner, M., Cronin, S., Smith, I., Handley, H., 2012. Magma evolution in the primitive, intra-oceanic Tonga arc: Rapid petrogenesis of dacites at Fonualei volcano. Journal of petrology 53, 1231-1253.

Turner, S., Hawkesworth, C., Rogers, N., Bartlett, J., Worthington, T., Hergt, J., Pearce, J., Smith, I., 1997. 238U-230Th disequilibria, magma petrogenesis, and flux rates beneath the depleted Tonga-Kermadec island arc. Geochimica et Cosmochimica Acta 61, 4855-4884.

Vallier, T.L., Stevenson, A.J., Scholl, D.W., 1985. Petrology of igneous rocks from Ata Island, Kingdom of Tonga, in: Scholl, D.W., Vallier, T.L. (Eds.), Geology and offshore resources of Pacific island arcs - Tonga region. Circum-Pacific Council for Energy and Mineral Resources, Houston, Texas.
Vaughan, R.G., Webley, P.W., 2010. Satellite observations of a surtseyan eruption: Hunga Ha'apai, Tonga. Journal of Volcanology and Geothermal Research 198, 177-186.

Vazquez, J.A., Reid, M.R., 2002. Time scales of magma storage and differentiation of voluminous high-silica rhyolites at Yellowstone caldera, Wyoming. Contributions to Mineralogy and Petrology 144, 274-285.

Venzke, E., Sennert, S.K., Wunderman, R., 2009. Reports from the Smithsonian's Global Volcanism Network, February 2009. Bulletin of Volcanology 71, 713-714.

Wendt, J., Regelous, M., Collerson, K.t., Ewart, A., 1997. Evidence for a contribution from two mantle plumes to island-arc lavas from northern Tonga. Geology 25, 611-614.

Wilson, C., Houghton, B., McWilliams, M., Lanphere, M., Weaver, S., Briggs, R., 1995. Volcanic and structural evolution of Taupo Volcanic Zone, New Zealand: a review. Journal of volcanology and geothermal research 68, 1-28.

Wohletz, K., Heiken, G., Ander, M., Goff, F., Vuataz, F.-D., Wadge, G., 1986. The Qualibou Caldera, St. Lucia, West Indies. Journal of volcanology and geothermal research 27, 77-115.

Worthington, T.J., Gregory, M.R., Bondarenko, V., 1999. The Denham caldera on Raoul Volcano: dacitic volcanism in the Tonga-Kermadec arc. Journal of Volcanology and Geothermal Research 90, 29-48.

Wright, I., Worthington, T., Gamble, J., 2006. New multibeam mapping and geochemistry of the 30-35 S sector, and overview, of southern Kermadec arc volcanism. Journal of Volcanology and Geothermal Research 149, 263-296.

Ziberna, L., Green, E.C., Blundy, J.D., 2017. Multiple-reaction geobarometry for olivine-bearing igneous rocks. American Mineralogist: Journal of Earth and Planetary Materials 102, 2349-2366. 
Table 1: Thermobarometry results on clinopyroxene, orthopyroxene and plagioclase crystals expressed as average and standard deviation for each sample group.

\begin{tabular}{|c|c|c|c|c|c|c|c|}
\hline \multirow[b]{2}{*}{$\begin{array}{l}\text { Eruptive } \\
\text { unit }\end{array}$} & \multicolumn{3}{|c|}{ cpx } & \multicolumn{2}{|c|}{ opx } & \multicolumn{2}{|c|}{$\mathrm{pl}$} \\
\hline & & $\begin{array}{c}\mathrm{T} \\
\text { average } \pm \\
\text { s.d. }\left({ }^{\circ} \mathrm{C}\right)\end{array}$ & $\begin{array}{c}\mathrm{P} \\
\text { average } \\
\pm \text { s.d. } \\
(\mathrm{MPa})\end{array}$ & & $\begin{array}{c}\mathrm{T} \\
\text { average } \pm \\
\text { s.d. }\left({ }^{\circ} \mathrm{C}\right)\end{array}$ & $\begin{array}{c}\mathrm{T} \\
\text { average } \pm \\
\text { s.d. }\left({ }^{\circ} \mathrm{C}\right)\end{array}$ & $\begin{array}{c}\mathrm{H}_{2} \mathrm{O} \\
\text { average } \pm \\
\text { s.d.(wt.\%) }\end{array}$ \\
\hline \multirow{2}{*}{$\begin{array}{c}\text { Lava }+ \\
\text { dyke }\end{array}$} & core & $1096 \pm 8$ & $153 \pm 52$ & core & $1053 \pm 6$ & \multirow{2}{*}{$999 \pm 4$} & \multirow{2}{*}{$4.8 \pm 0.4$} \\
\hline & rim & $1053 \pm 17$ & $168 \pm 53$ & rim & $966 \pm 20$ & & \\
\hline $\begin{array}{c}\text { Older } \\
\text { pyroclastics }\end{array}$ & & $1087 \pm 19$ & $144 \pm 57$ & & $1064 \pm 18$ & $996 \pm 5$ & $5.1 \pm 0.4$ \\
\hline $\begin{array}{l}\text { Cognate } \\
\text { enclaves }\end{array}$ & & $1106 \pm 25$ & $108 \pm 97$ & & $933 \pm 3$ & $1005 \pm 3$ & $4.6 \pm 0.2$ \\
\hline 2009 & & $1091 \pm 23$ & $181 \pm 100$ & & $1064 \pm 8$ & $998 \pm 7$ & $4.8 \pm 0.4$ \\
\hline $2014 / 15$ & & $1092 \pm 23$ & $140 \pm 81$ & & $1071 \pm 6$ & $1000 \pm 9$ & $5.0 \pm 0.5$ \\
\hline
\end{tabular}

Table 2. Mass balance model input data and results

\begin{tabular}{lrrrrrrrrr}
\hline & parent & derivate & feldspar $^{\mathrm{a}}$ & $\mathrm{cpx}^{\mathrm{b}}$ & opx $^{\mathrm{c}}$ & bulk frac & obs diff & calc diff & obs-calc \\
\hline $\mathrm{SiO}_{2}$ & 55.21 & 60.64 & 45.93 & 53.09 & 54.56 & 49.047 & 5.431 & 5.11 & 0.321 \\
$\mathrm{TiO}_{2}$ & 0.47 & 0.76 & 0 & 0.16 & 0.11 & 0.055 & 0.291 & 0.312 & -0.021 \\
$\mathrm{Al}_{2} \mathrm{O}_{3}$ & 16.89 & 13.85 & 33.75 & 1.72 & 0.92 & 20.821 & -3.041 & -3.072 & 0.03 \\
$\mathrm{FeOtot}$ & 9.14 & 11.01 & 0.87 & 10.34 & 16.08 & 5.659 & 1.87 & 2.358 & -0.488 \\
$\mathrm{MnO}$ & 0.16 & 0.18 & 0 & 0.28 & 0.38 & 0.13 & 0.015 & 0.021 & -0.007 \\
$\mathrm{MgO}$ & 5.00 & 2.72 & 0.17 & 16.62 & 25.72 & 8.341 & -2.281 & -2.477 & 0.197 \\
$\mathrm{CaO}$ & 11.11 & 7.87 & 17.94 & 17.78 & 2.22 & 15.133 & -3.237 & -3.2 & -0.036 \\
$\mathrm{Na} 2 \mathrm{O}$ & 1.70 & 2.32 & 1.31 & 0.02 & 0.01 & 0.793 & 0.625 & 0.674 & -0.049 \\
$\mathrm{~K}_{2} \mathrm{O}$ & 0.32 & 0.64 & 0.04 & 0 & 0 & 0.021 & 0.327 & 0.274 & 0.053 \\
$\mathrm{TOT}$ & 100.00 & 100.00 & 100.00 & 100.00 & 100.00 & & & & \\
& & & & & & & SSR $=$ & 0.39 \\
\multicolumn{2}{l}{ Fractionated abundance $(\%)=$} & 26 & 9.8 & 7.8 & & & & \\
\hline
\end{tabular}

${ }^{\mathrm{a}} \mathrm{HH} 08 \_f e l d 1$ 4; ${ }^{b} \mathrm{HH} 78 \_$maf3; ${ }^{\mathrm{c}} \mathrm{HH} 78 \_$mafl_2 